\title{
Consequences of accelerated aging for DNA integrity and seed germination of cowpea
}

\author{
S.E.M. Santos ${ }^{1}$, M.A. Gimenes ${ }^{2}$, J.O.L. de Oliveira Júnior ${ }^{3}$, M.F.Costa ${ }^{4}$, \\ M.F.C.Gomes ${ }^{5}$ and S.E.S.Valente ${ }^{6}$ \\ ${ }^{1}$ Programa de Pós-Graduação em Genética e Melhoramento, Campus da \\ Socopo, Teresina, PI, Brasil \\ ${ }^{2}$ EMBRAPA Recursos Genéticos e Biotecnologia, Brasília, DF, Brasil \\ ${ }^{3}$ EMBRAPA Meio-Norte, Teresina, PI, Brasil \\ ${ }^{4}$ Campus Amílcar Ferreira Sobral, Universidade Federal do Piauí, Floriano, \\ PI, Brasil \\ ${ }^{5}$ Campus Professor Ariston Dias Lima, Universidade Estadual do Piauí, São \\ Raimundo Nonato, PI, Brasil \\ ${ }^{6}$ Departamento de Biologia, Campus Ininga, Universidade Federal do Piauí, \\ Teresina, PI, Brasil
}

Corresponding author: S.E.S. Valente

E-mail: svalente@ufpi.edu.br

Genet. Mol. Res. 18 (3): gmr18304

Received March 21, 2019

Accepted June 25, 2019

Published July 04, 2019

DOI http://dx.doi.org/10.4238/gmr18304

ABSTRACT. Deterioration and loss of seed germination in the germplasm are related to the aging that occurs during the conservation process. The mechanisms related to the aging and death of seeds are not yet fully understood, but it is known that longevity can be affected by moisture content and temperature. We examined the effects of accelerated aging (A.A.) on the DNA of seeds of three different cultivars of cowpea (Vigna unguiculata) and compared the data to data from vigor and germination tests. The DNA of A.A.-seeds of BR 17 Gurgueia, BRS-Marataoã and BRS-Guariba cowpea cultivars were extracted and subjected to agarose gel electrophoresis. The increase in temperature, relative humidity and time used in A.A. culminated in a progressive and increasing degradation of seed DNA, which was expressed by continuous bands of DNA molecules with different lengths in the electrophoresis gel under all but the most extreme conditions (combinations $45^{\circ} \mathrm{C} / 72 \mathrm{~h}$ and $45^{\circ} \mathrm{C} / 96 \mathrm{~h}$ at $100 \%$ relative humidity) under which total disintegration of the DNA band was observed. This, in 
turn, was reflected in a progressive decrease in seed vigor. The combination of $35^{\circ} \mathrm{C} / 48 \mathrm{~h}$ was the most efficient for evaluating vigor in cowpea. The BR 17 Gurgueia and BRS-Guariba cultivars showed the highest values of vigor. A lack of DNA degradation in the laddering pattern on an electrophoresis gel is an indicator that DNA degradation and cell death in cowpea seeds did not occur by apoptosis but by nonprogrammed processes, such as Maillard reactions, lipid peroxidation and hydrolysis of sugars.

Key words: Genetic resources; Orthodox seeds; Seed bank; Vigna unguiculata

\section{INTRODUCTION}

Seeds are the natural propagation units for most species of higher plants and the main form of ex situ conservation of plant genetic resources (Peukert et al., 2016). Seed viability refers to the ability of the seed to germinate under suitable conditions (Bradbeer, 1988). In addition, seed quality has a pronounced effect on the development and productivity of an agricultural crop (Rahman and Cho, 2016).

The conventional seed conservation method used in germplasm banks involves dehydration to an extremely low moisture content (5\%) and maintenance in chambers with temperatures of approximately $-20^{\circ} \mathrm{C}$. During storage, several aspects have a direct effect on the seeds viability, such as water content in the storage, conservation packages, temperature and relative humidity of the air and the storage environment (Marques et al., 2014).

To preserve germplasm in a seed bank, it is essential to maintain seed quality and viability during storage (Hay et al., 2015). However, the deterioration and loss of germination in seeds are intrinsic to the process of conservation or storage of the seeds, since the seeds undergo an aging process, which can culminate in their death. Thus, the characteristic aging rates of the seeds of individual species constitute an essential parameter in the evaluation of storage, monitoring and regeneration conditions inherent in a germplasm bank (Walters et al., 2005). A disclosure of genetic factors contributing to adequate seed vigor would help to further increase yield potential and stability, the seed germination is influenced by both genetic as well as environmental factors (Hatzig et al., 2015). Reactive oxygen species (ROS) are the main causes of aging in seeds during prolonged storage, and their harmful effects must be repaired during germination so that the seed does not lose its full germination and vigor (Patnaik et al., 2010; El-Maarouf-Bouteau et al., 2011; Rajjou et al., 2012).

Seed germplasm banks are monitored using the direct germination test, which determines the proportion of living seeds capable of producing normal seedlings under favorable conditions (appropriate humidity, temperature, oxygen levels and substrate) (Delouche and Baskin, 1973). A useful test for germplasm conservation research is accelerated aging (A.A.), since it allows materials to be obtained at different stages of deterioration and thus allows conservation research to be carried out without the use of germplasm, which in many cases is rare and has limited seed numbers. The main rationale of A.A. is based on the fact that high-vigor seeds produce normal seedlings in the germination test after stress under conditions of high temperature and relative humidity (Krzyzanowski et al., 1991). In this sense, trials involving corn, watermelon, sorghum and 
onion seeds submitted to various A.A. regimes demonstrated that, with few exceptions, germination responses after A.A. and storage periods were closely associated (Delouche and Baskin, 1973). In addition, A.A. is correlated with seedling emergence conditions observed in a field crop.

Germination is a complex process in which a mature, embedded seed must resume metabolic activity at an efficient level and move rapidly from a maturation process to a programmed stage of development to prepare for the growth of a seedling (Nonogaki et al., 2010). Using only the germination test (G.T.) presents limitations if the objective in question is to regenerate degraded seeds (Wetzel et al., 2006). This is because a seed that does not germinate is considered to be missing from the collection. Because the number of accessions is very high in some collections, new low-cost methods complementary to G.T., such as molecular and biochemical markers of aging in seeds, are necessary to produce results that allow a fast, preventive analysis of seed germination (Donà et al., 2013).

Therefore, a better understanding of the cellular, molecular and biochemical mechanisms of the acquisition of vigor by seeds during their development, the continuity of germination and the deterioration of seeds due to aging is necessary. In this way, new seed germination markers could be developed that would complement the classic physiological tests (Corbineau, 2012). Currently, molecular approaches at the DNA, RNA and protein levels are being used to analyze important characteristics for ex situ conservation, such as longevity, tolerance to environmental stresses during germination, the uniformity and speed of germination of seeds and the establishment of seedlings (Rajjou et al., 2012). These studies are expected to develop new physiological seed-quality markers, which could be used in breeding programs as well as to establish biotechnological tools to increase crop yields.

The cowpea is a species of agricultural importance that possesses orthodox seeds and is thus conserved in cold chambers (Jain et al., 2017). Cowpea is socioeconomically important in the Northeast and North regions of Brazil, especially in rural areas and is a major source of dietary protein (Teixeira et al., 2010; Rodrigues et al., 2016: Torres et al., 2016). The relationship between the presence of degraded DNA and the effects of A.A. is a promising tool for the study of seed germination, which may contribute to the conservation and breeding programs of this species.

The objective of this study was to evaluate and study the effects of A.A. on seed DNA of cowpea and to compare them with those found in a germination test.

\section{MATERIAL AND METHODS}

\section{Obtaining plant material}

Seeds of the BR 17 Gurgueia, BRS-Marataoã and BRS-Guariba cowpea cultivars belonging to the same lot for each cultivar were used in all experiments. The seeds were from plants that were irrigated but not fertilized. The seeds were collected and stored in the seed chambers of the Embrapa Meio-Norte Germplasm Active Bank in Teresina, PI, Brazil. The three evaluated cultivars of cowpea are widely recommended for cultivation in the North and Northeast drought regions of Brazil (Teixeira et al., 2010).

The treatments were designated as follows: the first number represented a cultivar of cowpea ( 1 = BR 17 Gurgueia, 2 = BRS-Marataoã and 3 = BRS-Guariba). The second 
number referred to the accelerated aging temperature, which was $35^{\circ} \mathrm{C}$ or $45^{\circ} \mathrm{C}$. The third number represented the aging time $(1=48 \mathrm{~h}, 2=72 \mathrm{~h}$ and $3=96 \mathrm{~h})$. The controls were identified by just one digit each, which represented the cultivar of cowpea to which the seeds belonged ( $1=$ BR 17 Gurgueia, $2=$ BRS-Marataoã and $3=$ BRS-Guariba).

\section{Accelerated aging test}

The seeds assigned to the treatments were submitted to the accelerated aging test (A.A.), which was carried out using a gerbox-type plastic box with a suspended screen according to Silva et al. (2010). Samples of approximately 250 seeds of each cowpea cultivar were packed in polystyrene germination boxes $(11 \times 11 \times 3.5 \mathrm{~cm}-250 \mathrm{~mL} ; \mathrm{J}$.

Prolab $^{\circledR}$ ) containing $40 \mathrm{~mL}$ of distilled water, which formed a humid chamber. The boxes were sealed with plastic film and kept in a biochemical oxygen demand (BOD) incubator $\left(\mathrm{SPLABOR}^{\circledR}\right)$ at $35^{\circ} \mathrm{C}$ or $45^{\circ} \mathrm{C} \pm 0.5^{\circ} \mathrm{C}$ for the predetermined periods of 48,72 and $96 \mathrm{~h}$. The seeds were stored at $-20^{\circ} \mathrm{C}$ until DNA extraction; the integrity of the seeds was then evaluated by electrophoresis and consequently by the presence or absence of any evidence of degradation or DNA repair.

\section{Germination test}

The germination test (G.T.) was carried out according to the recommendations of the Rules for Seed Analysis (2009). Four replicates of 50 seeds were distributed uniformly on two sheets of $44 \times 34 \mathrm{~cm}$ germinating paper, moistened and covered with a third wet sheet.

After rolling the assemblies, the rolls were packed in incubation chambers at $25^{\circ} \mathrm{C}$. In another stage, normal seedlings (those intact or with small defects), abnormal seedlings (damaged, deformed or deteriorated) and dead seeds were counted after four and seven days of incubation. The percentage of germination of each replicate was calculated as the number of seeds that gave rise to normal seedlings divided by the 50 seeds of that replicate, and for each treatment, the percentage of germination corresponded to the simple arithmetic mean of the percentages obtained from the four replicates of 50 seeds.

Similar to Garcia et al. (2004), radicle emission of a length of at least $0.5 \mathrm{~cm}$ was adopted as the germination parameter. Seedlings that presented the primordial structures, i.e., radicle and plumule, were considered normal. The normal seedlings were used in the calculations of the percentage of germination

\section{Extraction of genomic DNA and DNA integrity}

The protocol described by Ferreira and Grattapaglia (1998) was used, with modifications. Subsequently, the DNA samples were quantified in a spectrophotometer $\left(\right.$ Pico $200^{\circledR}$ ) at an A260/280 ratio. A total of $1 \mu \mathrm{g}$ of each DNA sample was placed in a $1 \%$ agarose gel diluted in TBE buffer and visualized by electrophoresis. The gels were stained with ethidium bromide for $20 \mathrm{~min}$., visualized by exposure to UV light and photographed (Loccus ${ }^{\circledR}$ : L-Pix).

\section{Data analysis}


For the analysis of the data, the experimental design was completely randomized. The treatments for the germination test were arranged using a $3 \times 2 \times 3$ factorial scheme, i.e., three cowpea cultivars and three A.A. periods combined with two A.A. temperatures. The germination percentage data were analyzed by ANOVA using Assistat statistical software, version 7.6 beta. The Tukey test was applied at a 5\% probability level to compare the averages obtained from the treatments (Banzatto and Kronka, 2006). The treatments of the DNA integrity experiments followed a $3 \times 2 \times 3$ factorial scheme, with seeds of three cultivars of cowpea; three periods and two temperatures of accelerated aging. In addition to the treatments, the behavior of the negative controls was observed.

For the evaluation of nucleic acid integrity, five randomly selected seeds were used from each treatment. A quantitative evaluation of the degradation of the DNA of the respective treatments was carried out, in which a percentage was assigned to reflect the level of degradation. These values varied from $0 \%$ for highly intact DNA to $100 \%$ for drastically degraded DNA. DNA was considered to be of good integrity if it exhibited an intense band of DNA with a high molecular weight, DNA greater than 12 kilobases $(\mathrm{kb})$ long, and little "drag" of degraded DNA (DNA of less than or equal to $5 \mathrm{~kb}$ ) using the methodology of Kranner et al. (2011) and Faria et al. (2005).

\section{RESULTS AND DISCUSSION}

\section{Effects of Accelerated Aging on the vigor of cowpea seeds}

The germination rates of the BRS-Marataoã, BRS-Guariba and BR 17 Gurgueia cultivars were 96, 94 and $91 \%$, respectively. The high germination percentages obtained in this study indicate good post-harvest practices conferring physiological quality in the initial material, which is very important for the long-term conservation of seeds. There were significant differences $(\mathrm{P}<0.05)$ in the percentage of germination of cowpea seeds for all of the factors that were considered: cultivar type, temperature and time of A.A. (Table 1).

Table 1. Mean percentages of germination obtained after accelerated aging (A.A.), considering the effects of the factors cowpea cultivar, A.A. temperatures and A.A. time periods separately as well as the effect of the three-way interaction between the factors of cowpea cultivar and the combination of different temperatures and time periods of A.A.

\begin{tabular}{|c|c|c|c|c|c|}
\hline Cowpea cultivars & \multicolumn{5}{|c|}{ Mean percentages of germination } \\
\hline BR 17 Gurgueia & \multicolumn{5}{|c|}{$31.42^{\mathrm{a}}$} \\
\hline BRS-Marataoã & \multicolumn{5}{|l|}{$25.83^{\mathrm{b}}$} \\
\hline BRS-Guariba & \multicolumn{5}{|l|}{$35.67^{\mathrm{a}}$} \\
\hline Temperatures of A.A. & \multirow{2}{*}{\multicolumn{5}{|c|}{$46.06^{\mathrm{a}}$}} \\
\hline $35^{\circ} \mathrm{C}$ & & & & & \\
\hline $45^{\circ} \mathrm{C}$ & \multicolumn{5}{|l|}{$15.89^{b}$} \\
\hline Periods of A.A. & \multirow{2}{*}{\multicolumn{5}{|c|}{$60.00^{\mathrm{a}}$}} \\
\hline $48 \mathrm{~h}$ & & & & & \\
\hline $72 \mathrm{~h}$ & \multicolumn{5}{|l|}{$19.08^{b}$} \\
\hline $96 \mathrm{~h}$ & \multirow{2}{*}{\multicolumn{5}{|c|}{$\begin{array}{l}13.83^{\mathrm{c}} \\
\text { Mean percentages of germination* }\end{array}$}} \\
\hline \multirow{2}{*}{ Cultivars of cowpea } & & & & & \\
\hline & $35^{\circ} \mathrm{C} / 48 \mathrm{~h} \quad 35^{\circ} \mathrm{C} / 72 \mathrm{~h}$ & $35^{\circ} \mathrm{C} / 96 \mathrm{~h}$ & $45^{\circ} \mathrm{C} / 48 \mathrm{~h}$ & $45^{\circ} \mathrm{C} / 72 \mathrm{~h}$ & $45^{\circ} \mathrm{C} / 96 \mathrm{~h}$ \\
\hline BR 17 Gurgueia & $81.50^{\mathrm{aA}}$ & $33.50^{\mathrm{aB}}$ & $34.50^{\mathrm{bB}}$ & $0.00^{\mathrm{aC}}$ & $0.00^{\mathrm{aC}}$ \\
\hline BRS-Marataoã & $56.00^{\mathrm{bA}}$ & $15.00^{\mathrm{bC}}$ & $44.00^{\mathrm{bAB}}$ & $0.00^{\mathrm{aC}}$ & $0.00^{\mathrm{aC}}$ \\
\hline BRS-Guariba & $80.50^{\mathrm{aA}}$ & $34.50^{\mathrm{aC}}$ & $63.50^{\mathrm{aB}}$ & $1.00^{\mathrm{aD}}$ & $0.00^{\mathrm{aD}}$ \\
\hline
\end{tabular}


Regarding the cultivars of cowpea, regardless of the temperatures and time intervals used in A.A., the mean percentage of germination of BRS-Marataoã was significantly lower than those of BR 17 Gurgueia and BRS-Guariba, which did not differ themselves and presented the greatest vigor. This is valuable information for the conservation of the cowpea germplasm, and it can provide management strategies. The samples of the cultivars did not differ significantly in their initial germination power, and A.A. showed that they have different vigors. Based on this, the monitoring interval for the samples of the two most vigorous cultivars should be greater than that for the less vigorous one in a seed bank. In relation to the isolated effect of A.A. temperature, the average germination for each of the cowpea cultivars was significantly lower at $45^{\circ} \mathrm{C}$. However, only an effect of the time interval of A.A. was observed. A decrease in the percentage of germination was observed as the time of A.A. increased, with the lowest value obtained after $96 \mathrm{~h}$ and the highest value obtained after $48 \mathrm{~h}$.

These results confirm, as in other studies (Aveling and Powell, 2005; Dutra and Teófilo, 2007), that an increase in temperature as well as an increase in the time during the A.A. test reduces the germination of cowpea seeds. An increase in the temperature or water content of a seed during the A.A. process culminates in the transition of the seed content from a crystallized state to a viscous or molten state, which favors the occurrence of more rapid degradative reactions and, as a consequence, a decrease in seed germination (Murthy et al., 2003).

Based on the three-way interaction observed between the temperature and time of A.A., the combinations of $35^{\circ} \mathrm{C} / 48 \mathrm{~h}, 35^{\circ} \mathrm{C} / 96 \mathrm{~h}$ and $45^{\circ} \mathrm{C} / 48 \mathrm{~h}$ differentiated the evaluated cultivars into two distinct levels of vigor. In the combinations of $35^{\circ} \mathrm{C} / 48 \mathrm{~h}$ and $35^{\circ} \mathrm{C} / 96 \mathrm{~h}$, the BR 17 Gurgueia and BRS-Guariba cultivars showed equal vigor, which was superior to the vigor of BRS-Marataoã. In the $45^{\circ} \mathrm{C} / 48 \mathrm{~h}$ combination, the BR 17 Gurgueia and BRS-Marataoã cultivars showed the same vigor, which was inferior to the vigor of the BRS-Guariba cultivar. In the $45^{\circ} \mathrm{C} / 72 \mathrm{~h}$ and $45^{\circ} \mathrm{C} / 96 \mathrm{~h}$ combinations, a total loss of germination was observed. Considering this, the best combination for evaluating the vigor of the cowpea cultivars by the A.A. test was $35^{\circ} \mathrm{C} / 48 \mathrm{~h}$ because it revealed two distinct levels of vigor and the highest values of percentage of germination. The combinations of $45^{\circ} \mathrm{C} / 72 \mathrm{~h}$ and $45^{\circ} \mathrm{C} / 96 \mathrm{~h}$ were the worst combinations for evaluating the vigor of cowpea due to the total loss of germination in these combinations. The BR 17 Gurgueia and BRS-Guariba cultivars presented greater vigor than did the BRS-Marataoã cultivar. In other study, the best combination for evaluating the vigor of cowpea cultivars were $42^{\circ} \mathrm{C} / 48 \mathrm{~h}$ (Dutra and Teófilo, 2007). Considering the percentages of germination that were obtained, less drastic effects of the aging process on cowpea seeds are illustrated in the $35^{\circ} \mathrm{C} / 48 \mathrm{~h}$ and $35^{\circ} \mathrm{C} / 96 \mathrm{~h}$ combinations of A.A. However, for samples of BR 17 Gurgueia that have been conserved for a longer time, it is recommended that monitoring occurs at shorter intervals similar to those used for the BRS-Marataoã cultivar (results obtained in the $45^{\circ} \mathrm{C} / 48 \mathrm{~h}$ combination of A.A.). 


\section{DNA integrity of control seeds}

The negative controls, represented by unripe cowpea seeds (and not subjected to the quantitative evaluation of DNA integrity), showed low-intensity DNA degradation for all of the cultivars (Figure 1), predominantly varying between 1 and $12 \mathrm{~kb}$.

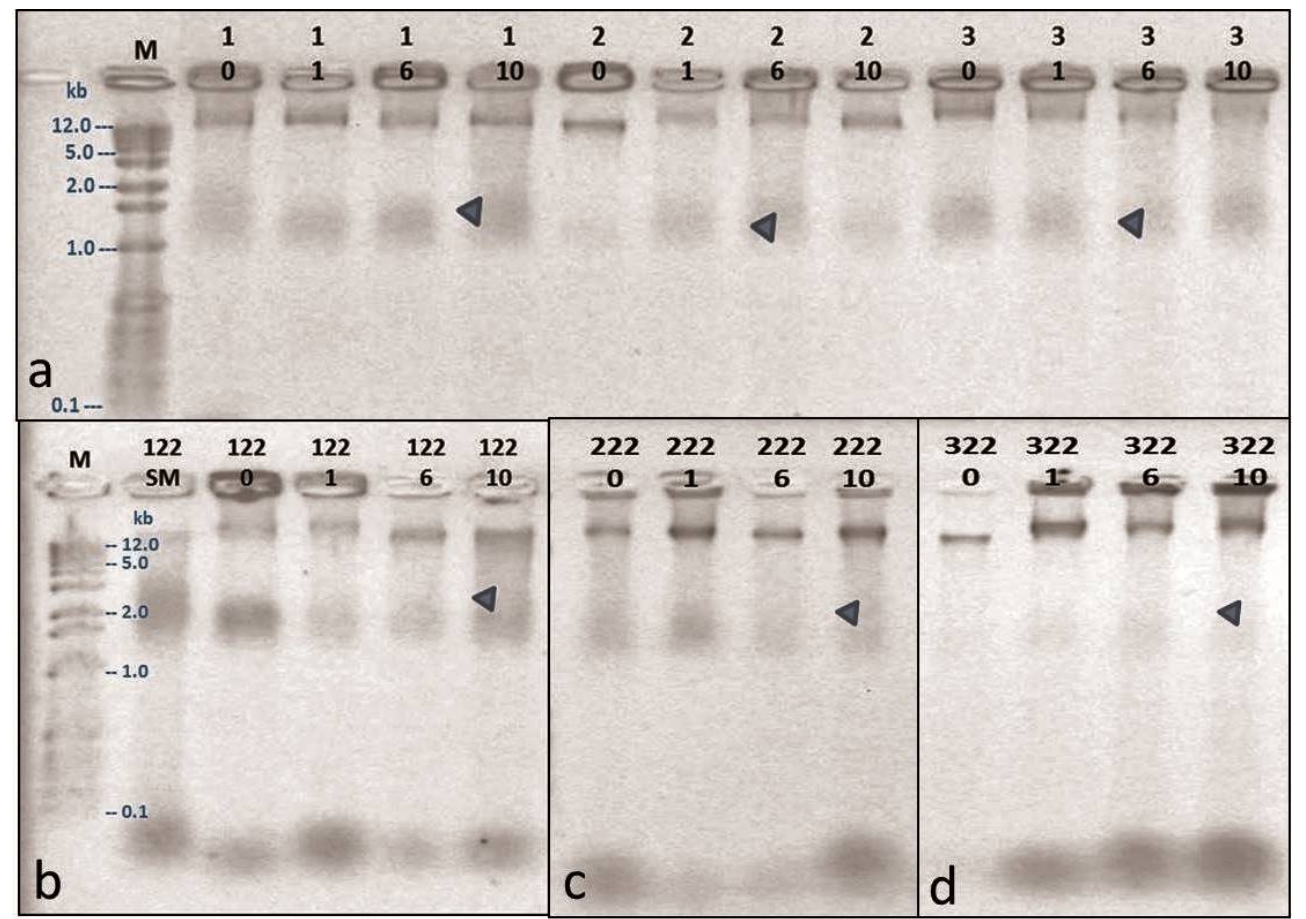

Figure 1. Electrophoresis of DNA samples $(1 \mu \mathrm{g})$ from seeds of cowpea on a 1\% agarose gel: 1 control to 3 control (a), Accelerated aging (A.A.) treatment seeds of the BR 17 Gurgueia cultivar (b), A.A. treatment seeds of the BRS-Marataoã cultivar (c), and A.A. treatment seeds of the BRS-Guariba cultivar (d); Arrows indicate degraded-DNA smears; $\mathrm{kb}=$ kilobases.

The occurrence of these small amounts of DNA degradation in viable orthodox seeds is normal since they have experienced dry maturation, which inevitably causes damage to DNA by the desiccation process. This has also been verified in the DNA of control seeds in Pisum sativum, in which traces of degraded DNA were observed in the non-aged seeds evaluating the effect of accelerated aging on nucleic acid integrity (Kranner et al., 2011).

\section{Effect of A.A. on the DNA of cowpea}

There were significant differences $(\mathrm{P}<0.01$ and $\mathrm{P}<0.05)$ in the DNA integrity of aged seeds among the three cultivars of cowpea, considering the effects of different cultivars and different temperatures and times of A.A. (Figure 2). 

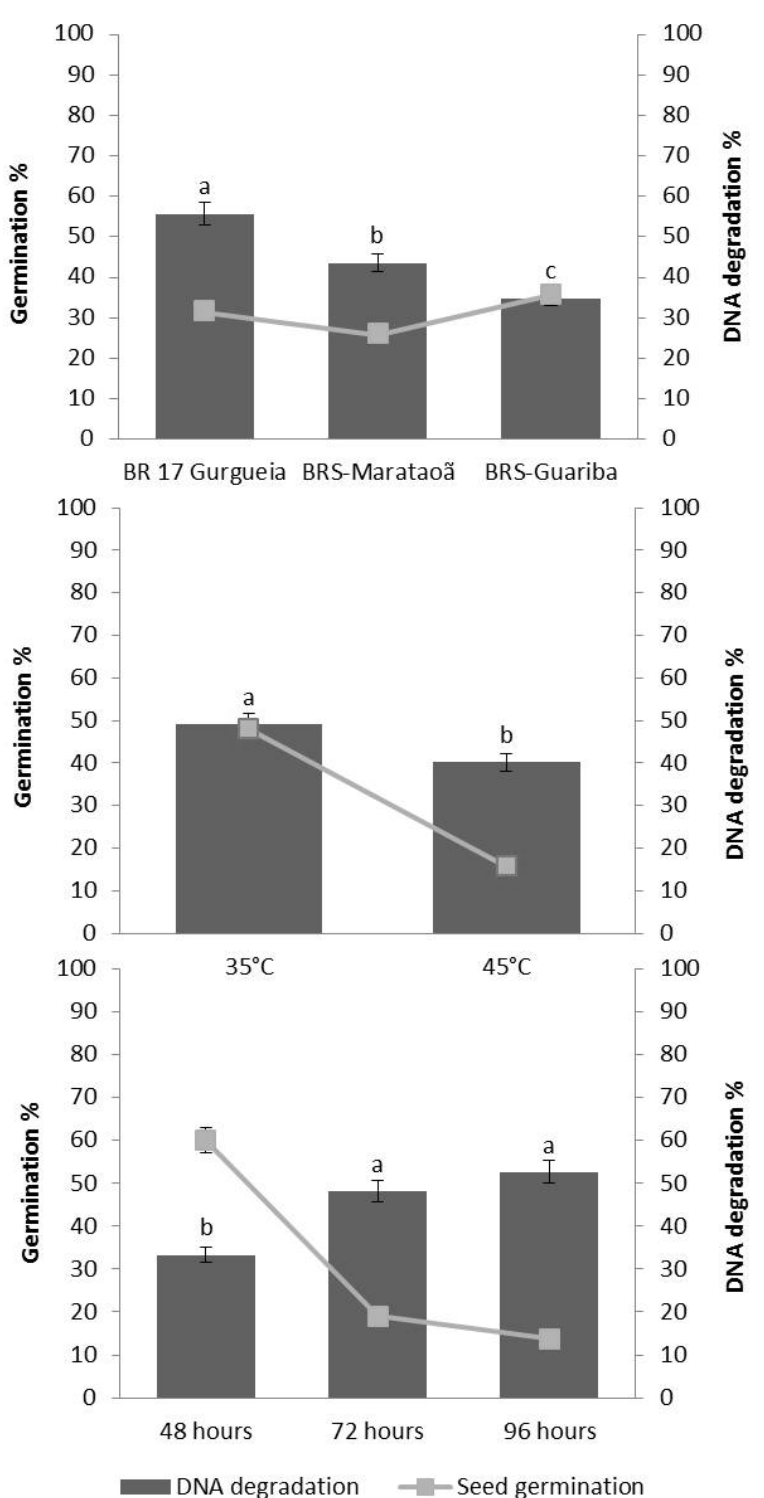

Figure 2. Average percentages for the separate effects of cultivar (top graph), temperature (middle graph) and time (bottom graph) on the intensity of degraded-DNA smears of cowpea seeds, together with germination data. Means followed by the same letter do not differ significantly based on the Tukey test at a significance level of $P<$ 0.01 ; bars indicate standard error.

The DNA integrity of cowpea seeds was also affected by the interactions between cultivar and temperature of A.A., cultivar and A.A. time, and temperature and time of A.A. In addition, there was a three-way interaction between cultivar, A.A. temperature and A.A. time (Figure 3). 


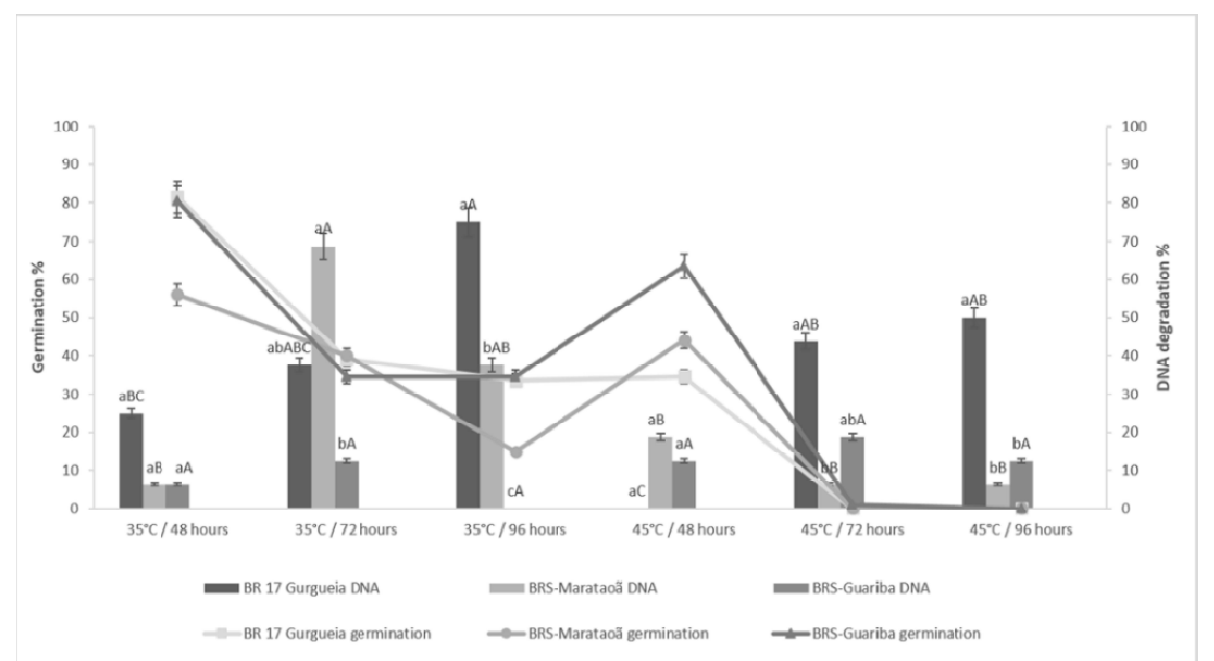

Figure 3. Average percentages of the intensity of degraded-DNA smears of cowpea, considering the effect of the interactions between the cowpea cultivar, Accelerated aging (A.A.) temperature and A.A. time, together with the averages obtained by the G.T; A.A. means accelerated aging; G.T. means germination test; Means followed by the same letter do not differ significantly based on the Tukey test with a significance level of $P<0.01$. Capital letters compare columns of the same color; lowercase letters compare columns of the same trio. Bars indicate standard error.

DNA degradation was observed among the treatments in all three cowpea cultivars (Figures $1 \mathrm{~b}, 1 \mathrm{c}$ and $1 \mathrm{~d}$ ). DNA degradation is determined visually based on the appearance of samples on an agarose gel during electrophoresis (the degraded DNA exhibits a characteristic stain or "drag"). This degradation must be associated with the production of ROS that are indicated as the main cause of the deterioration of aged seeds (Corbineau, 2012). ROS are products and also propagators of the lipid peroxidation reaction, an unscheduled biochemical process that causes DNA damage and natural or artificial aging in orthodox seeds (Murthy et al., 2003; Kranner et al., 2010).

\section{Relationship between DNA degradation and the decline of vigor in cowpea}

At $35^{\circ} \mathrm{C}$, the BR 17 Gurgueia cultivar showed a decline in germination power after $72 \mathrm{~h}$ of A.A. and an increase in the degradation of DNA in the seeds after $96 \mathrm{~h}$ of A.A. (Figure 3). At $45^{\circ} \mathrm{C}$ and after $48 \mathrm{~h}$ of A.A., the vigor of BR 17 Gurgueia was reflected in the lower DNA degradation compared to that in the combination of $35^{\circ} \mathrm{C} / 96 \mathrm{~h} \mathrm{A.A.,} \mathrm{but} \mathrm{the}$ DNA degradation was similar to that in the $35^{\circ} \mathrm{C} / 48 \mathrm{~h}$ and $35^{\circ} \mathrm{C} / 72 \mathrm{~h}$ combinations. The total loss of germination in the $45^{\circ} \mathrm{C} / 72 \mathrm{~h}$ and $45^{\circ} \mathrm{C} / 96 \mathrm{~h}$ combinations was corroborated by higher degradation of DNA than that in the $45^{\circ} \mathrm{C} / 48 \mathrm{~h}$ combination of A.A. However, these values were similar to those observed in all A.A. time intervals at $35^{\circ} \mathrm{C}$.

In the BRS-Marataoã cultivar, the decrease in germination power at $35^{\circ} \mathrm{C}$ after $72 \mathrm{~h}$ of A.A. was reflected in the increase in DNA degradation (Figure 3). After $96 \mathrm{~h}$ at this temperature, the germination power dropped again; however, the degradation of the DNA in that same interval did not differ significantly from the values observed after 48 and $72 \mathrm{~h}$ of A.A. at $35^{\circ} \mathrm{C}$. After $48 \mathrm{~h}$ of A.A. at $45^{\circ} \mathrm{C}$, the germination percentage of BRS-Marataoa did 
not differ significantly from the values observed in the $35^{\circ} \mathrm{C} / 48 \mathrm{~h}$ and $35^{\circ} \mathrm{C} / 72 \mathrm{~h}$ combinations. On the other hand, DNA degradation consistently showed the same value as in the $35^{\circ} \mathrm{C} / 48 \mathrm{~h}$ combination. After 72 and $96 \mathrm{~h}$ of A.A., there was a total loss of germination power, and DNA degradation remained the same as the lowest value observed in the BRS-Marataoã cultivar.

Considering the BRS-Guariba cultivar, after $72 \mathrm{~h}$ of A.A. at $35^{\circ} \mathrm{C}$, germination power decreased and remained constant after $96 \mathrm{~h}$ (Figure 3). At $45^{\circ} \mathrm{C}$ and after $48 \mathrm{~h}$ of A.A., the germination power was lower than that observed in the $35^{\circ} \mathrm{C} / 48 \mathrm{~h}$ combination. After 72 and $96 \mathrm{~h}$ of A.A. at $45^{\circ} \mathrm{C}$, there was a complete loss of germination power. In all combinations of time and temperature of A.A., the percentage of degraded DNA remained the same.

A decline in or maintenance of low percentages of degraded DNA was observed in cowpea beans subjected to more severe conditions of A.A., despite the decrease in their germination power, e.g., in the BR 17-Gurgueia and BRS-Marataoã cultivars at $45^{\circ} \mathrm{C} / 72 \mathrm{~h}$ and $45^{\circ} \mathrm{C} / 96 \mathrm{~h}$ and in the BRS-Guariba cultivar at $35^{\circ} \mathrm{C} / 72 \mathrm{~h}, 35^{\circ} \mathrm{C} / 96 \mathrm{~h}, 45^{\circ} \mathrm{C} / 48 \mathrm{~h}$, $45^{\circ} \mathrm{C} / 72 \mathrm{~h}$ and $45^{\circ} \mathrm{C} / 96 \mathrm{~h}$. As a consequence, there was a lower percentage of degraded DNA at $45^{\circ} \mathrm{C}$, despite the decrease in temperature (Figure 2).

These results are surprising. First of all, increases in temperature and the time of exposure potentiate A.A. damage. Second of all, the vigor of the seeds evaluated by the germination test decreased with increasing temperature and time. However, according Kranner et al. (2011), what may have occurred was more degradation of the component nucleosomes of DNA from the "drag" DNA that could be confused with a reversal of damage or enhancement of integrity by repair mechanisms.

Similar results were found by Kranner et al. (2011), who also observed a clear decrease in DNA degradation in seeds of another legume, Pisum sativum, submitted to A.A. $\left(50^{\circ} \mathrm{C}\right.$ for 0,25 or 55 days) during soaking $(0,6,10,15,20,50$ and $80 \mathrm{~h})$. This conclusion, supported by the vigor results obtained by the G.T., demonstrates the aggravation of cell damage, including DNA damage, in cowpea seeds. For seeds that are drastically damaged by aging, it shows the intensification of degradative reactions of macromolecules, including DNA.

The observed degradation in the DNA of aged bean seeds did not present the laddering pattern found by Faria et al. (2005), Kranner et al. (2011) and El-MaaroufBouteau et al. (2011) in artificially aged seeds of Medicago truncatula, Pisum sativum and Helianthus annuus, respectively. This suggests that the degradation and death in these cowpea seeds occurred through other pathways, but not through the process of apoptosis. This degradation may be related to unscheduled biochemical processes associated with the natural or artificial aging and death of orthodox seeds that also cause DNA damage. These processes would be, as stated by Murthy et al. (2003), lipid peroxidation, glycosylation and Maillard reactions.

The Maillard reactions are a set of complex serial reactions that begin with a simple initial and non-enzymatic attack of amino groups of proteins and protein / nucleic acid complexes by reducing sugars and aldehydes (Murthy et al., 2003). According to these authors, lipid peroxidation and sugar hydrolysis (formation of reducing sugars) are coupled to Maillard reactions during the aging of seeds. 
The attack of amino groups of DNA bases by reducing sugars forms adducts that inhibit the functions of the DNA molecule. In addition, the adsorption of these adducts can be characterized by the fact that the adducts are chemically rearranged and can bind glycosidic bonds between purine bases and deoxyriboses, which leads to the purification, $\beta$ elimination and breaking of DNA strands (Bucala et al., 1984). The consequences of repeated and prolonged DNA damage from non-enzymatic glycosylation include changes in structure and function, resulting in decreased repair, replication, and transcription processes as well as increased chromosomal aberrations and breaks in the ribbons of DNA with the aging process (Lee, 1987).

\section{CONCLUSIONS}

DNA integrity is an important biochemical indicator of the conservation status of cowpea seeds. This parameter, combined with a germination test, efficiently characterizes the vigor of A.A. seeds. In addition, the study of DNA integrity in cowpea seeds and other species with orthodox seeds may be a promising tool in the monitoring of seeds in longterm conservation seed banks.

\section{ACKNOWLEDGMENTS}

This work was supported by the "Fundação de Amparo a Pesquisa do Estado do Piauí" (FAPEPI) and " Coordenação de Aperfeiçoamento de Pessoal de Nível Superior" (CAPES).

\section{REFERENCES}

Aveling TAS and Powell AA (2005). Effect of seed storage and seed coat pigmentation on susceptibility of cowpeas to pre-emergence damping-off. Seed Sci. Technol. 33: 461-470.

Banzatto DA and Kronka SN (2006). Agricultural experimentation. FUNEP, Jaboticabal.

Bradbeer JW (1988). Seed Viability and Vigour. In: Seed Dormancy and Germination (Bradbeer JW, ed.). Tertiary Level Biology. Springer, Boston.

Bucala R, Model P and Cerami A (1984). Modification of DNA by reducing sugars: a possible mechanism for nucleic acid aging and age-related dysfunction in gene expression. Proc. Natl. Acad. Sci USA. 81: 105-109.

Corbineau F (2012). Markers of seed quality: from present to future. Seed Sci. Res. 22: 61-68.

Delouche JC and Baskin CC (1973). Accelerated aging techniques for predicting the relative storability of seed lots. Seed Sci. \& Technol. 1: 427-452.

Donà M, Balestrazzi A, Mondoni A, Rossi G, et al. (2013). DNA profiling, telomere analysis and antioxidant properties as tools for monitoring ex situ seed longevity. Ann. Bot. 111: 987-998.

Dutra AS and Teófilo EM (2007). Envelhecimento acelerado para avaliar o vigor de sementes de feijão-caupi. Rev. Bras. Sementes. 29(1): 193-197.

El-Maarouf-Bouteau H, Mazuy C, Corbineau F and Bailly C (2011). DNA alteration and programmed cell death during ageing of sunflower seed. J. Exp. Bot. 62: 5003-5011.

Faria JMR, Buitink J, Lammeren AM and Hilhorst HWM (2005). Changes in DNA and microtubules during loss and reestablishment of desiccation tolerance in germinating Medicago truncatula seeds. J. Exp. Bot. 56: 2119-2130.

Ferreira ME and Grattapaglia D (1988). Introduction to the use of molecular markers on genetic analysis. Brasília: Cenargen- Embrapa.

Garcia LC, Nogueira AC and Abreu DCA (2004). Accelerated aging on Anadenanthera colubrina (Vellozo) Brenan Mimosaceae seed vigour. Cienc. Florest. 14(1): 85-90.

Hatzig SV, Frisch M, Breuer F, Nesi N, et al. (2015). Genome-wide association mapping unravels the genetic control of seed germination and vigor in Brassica napus. Front. Plant Sci. 6: 221.

Hay F, Timple S and Van Duijn B (2015). Can chlorophyll fluorescence be used to determine the optimal time to harvest rice seeds for long-term genebank storage? Seed Sci. Res. 25: 321-334. 
Jain A, Srinivasan K, Yadav RP and Mishra A (2017). Effect of moisture content on in vitro regeneration of embryonic axis explants of cowpea (Vigna unguiculata L.). Legume Res. 40: 74-79.

Kranner I, Chen H, Pritchard HW, Pearce SR, et al. (2011). Inter-nucleosomal DNA fragmentation and loss of RNA integrity during seed ageing. Plant Growth Regul. 63: 63-72.

Kranner I, Minibayeva FV, Beckett RP and Seal CE (2010). What is stress? Concepts, definitions and applications in seed science. New Phytol. 188: 655-673.

Krzyzanowski FC, França-Neto JB and Henning AA (1991). Relato dos testes de vigor disponíveis para as grandes culturas. Informativo ABRATES. 1: 15-37.

Lee AT (1987). The nonenzymatic glycosylation of DNA by reducing sugars in vivo may contribute to DNA damage associated with aging. Age. 10: 150-155.

Marques ER, Araújo EF, Araújo RF, Martins-Filho S, et al. (2014). Seed quality of rice cultivars stored in different environments. J. Seed Sci. 36: 32-39.

Murthy UMN, Kumar PP and SunWQ (2003). Mechanisms of seed ageing under different storage conditions for Vigna radiata (L.) Wilczek: lipid peroxidation, sugar hydrolysis, Maillard reactions and their relationship to glass state transition. J. Exp. Bot. 54: 1057-1067.

Nonogaki H, Bassel GW and Bewley JD (2010). Germination - still a mystery. Plant. Sci. 179: 574-581.

Patnaik AR, Achary VMM and Panda BB (2010). Comet assay to asses DNA damage and genotoxic stress in plants. In: Plant Genome: Biodiversity, Conservation and Manipulation (Roy BK, Chaudhary R, Sinha RP, eds.). Narosa Publications, New Delhi.

Peukert M, Dittbrenner A, Meinhard J, Fischer U, et al. (2016). Metabolic variability of seed material from diverse sugar beet (Beta vulgaris L.) genotypes and of different germination capacities. Seed Sci. Res. 26: 57-66.

Rahman A and Cho B (2016). Assessment of seed quality using non-destructive measurement techniques: A review. Seed Sci. Res. 26: 285-305.

Rajjou L, Duval M, Catusse J, Gallardo K, et al. (2012). Seed germination and vigor. Annu. Rev. Plant Biol. 63: 507-533.

Rodrigues EV, Silva KJD, Rocha MM and Bastos EA (2016). Diallelic analysis to obtain cowpea (Vigna unguiculata L. Walp.) populations tolerant to water deficit. Genet. Mol. Res. 5(2): gmr.15027996.

Silva JB, Lazarini E and Sá ME (2010). Behavior of soybean cultivar seeds subjected to different periods of accelerated aging. Biosci. J. 26: 755-762.

Teixeira IR, Silva GC, Oliveira JPR, Silva AG, et al. (2010). Agronomic performance and quality of seeds of cowpea cultivar in the Brazilian "cerrado" region. Rev. Cienc. Agron. 41(2): 300-307.

Torres FE, Teodoro PE, Rodrigues EV, Santos A, et al. (2016). Simultaneous selection for cowpea (Vigna unguiculata L.) genotypes with adaptability and yield stability using mixed models. Genet. Mol. Res. 15(2): gmr.15028272.

Walters C, Wheeler LM and Grotenhuis JM (2005). Longevity of seeds stored in a genebank: species characteristics. Seed Sci. Res. 15: 1-20.

Wetzel MMVS, Ramos SRR and Pereira-Neto LG (2006). Comportamento das sementes de feijão-caupi no armazenamento a longo prazo. In: Congresso Nacional de Feijão-caupi, Reunião Nacional de feijão-caupi. Anais (Embrapa Meio-Norte ed). Embrapa Meio-Norte, Teresina. 